\title{
Efforts at the Boundaries: Social Media Use in Swedish Municipalities
}

\author{
Livia Norström $^{1}$ and Monika Hattinger ${ }^{2}$ \\ ${ }^{1}$ University West, Department of Business \& IT, Trollhättan, Sweden \\ livia.norstromehv.se \\ ${ }^{2}$ University West, Department of Engineering Science, Trollhättan, Sweden \\ monika.hattinger@hv.se
}

\begin{abstract}
Social media is used by the majority of Swedish municipalities. However, the highly interactive features of social media are often not taken advantage of. The study aims to get a better understanding of why social media is not used to its full potential in the municipality. Findings from an interview study with communicators in three Swedish municipalities reveal that the motivation for using social media is often difficult to turn into action. Tensions emerging in the use of social media result in hesitation, uncertainty and a slowing down of work practice. The processes of managing the tensions are characterized by boundary crossing between different communities, such as municipal communicators, elected officials and citizens, with social media itself as an equally important actor. The processes of boundary crossing by the municipal communicators are discussed in terms of learning processes and new emerging competences that might redefine the role of the municipal communicator and hence perhaps the public servant in general.
\end{abstract}

Keywords. Social Media; Municipalities; Communicators; Public Servants; Eparticipation; Boundary Crossing; New Competence

\section{Introduction}

Social media in government has been extensively studied because of its believed potential to support the work of reaching out with information to old and new audiences, and because of its two-way communication characteristics, making available more direct communication with the target audience [1]. Social media is assumed to have potential to stimulate new opportunities for governments to share information, create dialogue, co-create content and network [2]. It generates a new and unique source of information for both governments and citizens, created in interaction with each other [3]. Beyond the possibilities of providing information and making communication available, social media enables increased transparency, which is important for building trust. Easy access 
and trust are necessary conditions for an increased engagement and participation [1]. Social media is also a place where many people spend their time and live their lives [4, $5,6,7,8]$. Even though different social media services come and go, the citizens' adoption of Internet and social media is still increasing. In 2015, 93\% of the Swedish population had Internet connection, while $70 \%$ of these Internet users used Facebook (the most common social media service) now and then, and 50\% used it every day [7].

Thus, social media is an interesting possibility for e-government to explore to improve activities and services, and to strengthen democracy with increased e-participation [9]. E-government in this study is used as a term for processes related to digitalization of government with the aim to create a better, i.e., more open, transparent and accessible government [10]. E-participation is used as a subcategory of e-government and a concept that specifically addresses and problematizes the relationship between government and citizens [11, 12, 13]. E-participation tackles the transformation of power, work and activity in government, by means of Information Technology (IT) [14]. In this piece of research it is studied through the use of social media.

Municipalities represent the governmental body with the closest relationship to citizens and with activities directly linked to citizens' everyday life such as work opportunities, education and infrastructure [15]. The physical nearness and relevance of activities motivate citizens' engagement with the municipality [16]. This, in combination with the speed and directness of social media, has made social media a popular approach among municipalities for reaching out to citizens. From a Swedish municipality context, Facebook is the most commonly used social media site. In 2014, 67\% of Swedish municipalities had a general Facebook page [17].

The explosion of social media use in municipalities has generated a huge quantitative, as well as qualitative variety of use, and questions still prevail as to whether and how social media can support a transparent, participatory government [18, 19]. According to Khan et al. [1] and Dixon [20] there is little evidence in current research showing that social media use by government leads to increased citizen engagement and involvement. Even if governments do see the potential with IT for better government, most efforts have been focused on e-service and e-administration, rather than on activities more dedicated to democracy, such as increased citizen influence and improved governance [21]. From a citizen perspective, e-government is not experienced either as an activity that stimulates engagement in democratic processes [22].

Several studies suggest that governments are lagging behind in the adoption of social media compared to adoption by private people and several scholars argue that social media is not used to its full democratic potential [18, 19, 23]. Instead governments tend to use social media in a top-down manner. Information is mainly pushed out to citizens and the governments have problems keeping up with the quantity and speed of information [22]. The capabilities of social media as a generator of user content [24] is not taken advantage of. Rather social media is conceptualized as equivalent to traditional media and is used mainly for broadcasting, marketing and advertising [23].

In sum, interaction between government and citizens seems to be going on with tools that have potential to give citizens more power over the agenda for the interaction, but still the service is mainly one-way, top-down directed without much space for citizen influence. Hence, e-government might make everyday life more convenient to citizens with accessible information and good service, but it is critical whether it contributes to democratic decision-making for societal change. 
To understand the reason for this the different relationships within e-government need to be problematized. Recent research show how democratic processes are primarily taking place between elected officials and citizens, while the relationship between the public servants and citizens are mainly characterized by service i.e. providing information $[21,25,26]$. When social media is used by public servants this servicerelationship to citizens is challenged. Societal dialogues become part of the public servants' everyday work, as well as considerations of how to reach out, to what groups of citizens, with what kind of information etc. - in order to get feedback and be responsive. Public servants become important actors, not only as providers of information, but also as facilitators of democratic logics. The question is though if the public servants have the competence required for this new task and if they understand and agree on the potential of social media as a tool for increased democracy? According to Charalabidis \& Loukis [27], success with social media for participation and democracy needs new organizational units with experts in the new channels, who can analyse and act on the quantitative and qualitative data generated in social media.

The current study is motivated by the curiosity to gain deeper understanding of why participatory and democratic aspects of social media are not always applied by municipalities. It aims to give a contribution to the understanding of challenges of social media use in the municipality, with a special focus on public servant communicators' (further referred to as 'communicators') interaction with the citizens on the general municipal Facebook page. The communicators are of special interest for the study since they serve as facilitators for how social media is used in the municipality and their work is constituted by a mediating role at the boundaries between the main municipal stakeholder groups: public servants, citizens and elected officials [26, 28].

Hence, the study seeks to detect and understand how communicators in the municipality handle emerging tensions and dynamics in their daily work at the boundaries between public servants, citizens and elected officials and how new work tasks emerge and challenge the professional identity. The research question is: How is social media use challenging the work and identity of communicators in the municipality?

\section{Social Media in the Municipality}

There has always been a mutual dependence between government and citizens [29]. Citizens depend on government for infrastructure and service in their everyday life and government needs citizens' trust and feedback for future work. However, with social media use in government this relationship is challenged in a variety of ways related to the foundation of social media technology.

Firstly, social media use is characterized by three different affordances: editability, persistence and spreadability [30]. 'Editability' enables the user to change the posts before sharing, 'persistence' of text, image and sound allows posts to be stored and used for later purposes, while 'spreadability' relates to functions that enable the user to directly spread the post to a large and unidentified audience [31]. All three features are of importance for the practice of social media since people must, to some extent, accept that their actions are public [30].

Secondly, social media can be understood as a technology and a philosophy based on 'user-generated content' [24] which changes the conception of online communication 
from a top-down, linear sender-receiver, push view, to a network perspective $[32,33]$. User-generated content can be seen as a product of 'procrastinated bindings' which means the design of social media, i.e., the information filling it and the rules set up for use, is decentralized and distributed in ecosystems and platforms [34]. It is no longer the service provider (e.g. Facebook) and the organization (e.g. government) implementing the system that drives the creative process of defining functions and purpose of use. Rather, the service provider enables a space for activity, where the user of the service creates meaning in the actual use. In the case of social media in the municipality, meaning is created in the interaction between communicators, elected officials, citizens, and the service provider (in this case Facebook). The challenged relationship between egovernment and citizens can thus be partly related to the social media use of these different actors.

Consequently, social media affords new arenas for citizens to engage in municipal issues, where they get fast response and avoid bureaucracy. Today most societal discussions take place away from the governmental arenas on external social media platforms [35]. The user-generated content approach means that government is no longer only informing and serving citizens. Transparency is taken to a higher level by making conversations between government and citizens potentially visible to everyone. The openness of the conversations in social media gives opportunities for learning for both municipal workers and citizens. It provides essential data to the municipality which is necessary to make better decisions and be more relevant in the information to citizens about decisions made. It also helps citizens to understand why and how decisions are being processed [23]. Responsiveness from the government's side means being transparent, accessible and relevant, which has proven to increase citizens' trust in government [36] and hence, increased trust motivates engagement [2, 23].

Three different strategies for social media use in an organization are detected in the literature: push, pull and networking strategy [37]. A push strategy means providing information while a pull strategy relates to the initiatives to direct the audience to the intended communication channels. Push and pull strategies are effective for information sharing purposes. In a government context that could be e.g. news about weather, construction work, traffic jams, and natural disasters. A networking strategy implies using social media to stimulate the audience to participate in decision-making processes by commenting, giving feedback and discussing [1]. In the context of the government organization in short the push and pull strategies are content-driven and only facilitate one-way communication, while the networking strategy is action-driven and promotes two-way social interactions between the government and citizens' [1, p. 100].

A 'Facebook page' is an example of a social media service that is commonly used by governments in the interaction with citizens. It is an open online page visible to everyone on the Internet and can be set up by public profiles, businesses and organizations who wish to have a professional presence on Facebook. Anyone can connect with a Facebook page by 'liking' the page and thereby become a follower of the page [38]. However, to increase the possibilities of getting the news flow of a Facebook page in the private news flow, the follower not only needs to click 'like' at the page, s/he must also interact with the page, such as like, share and comment on posts on the page [39].

\section{Boundary Objects and Boundary Crossing}

With help of theories of boundary crossing and boundary objects $[40,41]$ the study 
seeks to detect and understand how communicators in the municipality handle emerging tensions and dynamics in their daily work at the boundaries between public servants, citizens and elected officials and how work and professional identity of the communicators are negotiated in the social media practice.

According to Akkerman and Bakker [40], boundaries exist within all workplaces between diverse communities such as groups with different expertise and working tasks and different sociocultural background. However, boundaries can only be conceptualized between different communities. The goal can be the same for the different communities but when they work together contradictions and negotiations might arise. By studying the boundaries between the communities, sociocultural differences might be apparent. It is also on the boundaries where collaboration can potentially be developed and where processes of change in practice can take place and new practices develop without consensus between the different actors [40].

Individuals working at the boundaries can be understood as 'boundary crossers'. These people build bridges between the different communities but they are also representing both communities. It can be hard work being a boundary crosser but they often gain credibility in the long run for changing the work practice. 'Boundaries' both connect and disconnect different communities. They also define no man's land. That implies that boundary crossers represent all different groups of people and practices involved in the interaction but also practices beyond the ones already existing. Boundary crossers both uphold agreed boundaries and define new. In that sense boundaries are blurred and ambiguous. 'Boundary objects' have different meanings for different sociocultural communities but they have a structure that makes them recognizable and that, to some extent, unites people using them. The objects become boundary objects and get meaning in the interaction between the different communities. Boundary objecs are also flexible in the sense that they sometimes have a boundary function and sometimes not. Boundary objects tend to be invisible but if we unpack them learning occasions might be visible [40].

\subsection{Learning Mechanisms at the Boundaries}

Akkerman and Bakker [40] use the concept of learning in a broad sense as a process of gaining new understanding, creating new practices and developing the institution. They have identified four different learning mechanisms occurring at the boundaries: 'Identification', 'Coordination', 'Reflection' and 'Transformation'. Two of the learning mechanisms - Identification and Coordination - are used in this paper to understand the boundary practice of the communicators on the municipal general Facebook page.

'Identification' relates to the learning potential of identifying related and competing practices, as well as new and competing practices. Two different identification processes are ongoing in the meeting at boundaries: 'Othering' and 'Legitimating coexistence'. Othering is a process of reshaping boundaries. When different practices meet tensions arise related to whom to identify oneself with. People tend to compare practices, and what was thought of as different practices might be more similar than expected. Overlapping practices can be perceived as a threat and consequently lead to questioning one's own identity. In the process of othering boundaries between different practices are constantly redefined and shaped in order to protect one's own 
identity in relation to competing practices. In the process of 'legitimating co-existence' on the other hand, a profession can change its identity to continue to exist and be accepted to co-exist with the new competitors. Acceptance or legitimization of different identities can be hard, sometimes political and often sensitive.

Learning at the boundaries is also about 'coordination' of work when consensus among participants does not exist. The learning potential in the process of coordination is not about reshaping boundaries, as in the case of identification. Coordination is rather about overcoming the boundaries to get continuity in the work flow. Four necessary resources are highlighted for coordination work: 'Communicative connections', 'Efforts of translation', 'Enhanced boundary permeability' and 'Routinization'. 'Communicative connections' are vital for coordination. These connections serve as common objects where information is passed through, but the meaning of it can come out differently for different communities. Communicative connections can be established with help of boundary objects that are shared by many. 'Efforts of translation' are processes of trying to translate the information into meaningful communication for different communities. Efforts of translation can increases the possibility of common agreement. Boundary objects can help in the process of translation. 'Enhanced boundary permeability' means that interactions on the boundaries run smoothly with no effort and no problematic discontinuities. 'Boundary permeability' can be enhanced when boundaries are repeatedly crossed. 'Routinization' refers to the process of finding regular ways of acting, i.e., to automate the practice.

Social media practice as defined above is used in this paper in order to move away from the two extreme but common scholarly conceptualizations of social media as either 1) a bare technology determining the activity and change of users and organizations or 2) something (undefined) that is socially constructed in the organization $[42,43]$. Instead, in this study, communicators, citizens and social media, together and in interaction, are conceptualized as equally important actors constituted in the boundary practice.

\section{Method}

The paper reports on findings from a study of social media use in three Swedish municipalities. It explores work conditions for communicators at the municipal department of communication. The study focuses on the communicators' social media interactions with citizens on Facebook. Strategic and/or hands-on work related to social media was included in the work tasks for all of the communicators and that has been the criteria for the selection of respondents for the study.

\subsection{Data Collection}

Eight communicators at the three respective city hall communication departments were interviewed; two in one municipality, and three in each of the other two municipalities. The eight respondents had, to some extent, different functions and tasks. Five of them were either managers or communicators responsible for the overall internal and external communication including general responsibility for social media activities. That means representing the whole municipality in central and official social media 
channels and to support, organize, and to some extent, control the social media work in other administrative departments. Out of the additional three respondents, one had a specialization in consumer counselling, one was a coordinator of democracy issues, and finally one was an IT manager responsible for IT infrastructure.

Social media was part of the communication strategy in all three municipalities and was supposed to complement other communication channels for external communication with citizens and organizations such as websites, online forms, telephone, e-mail, e-services and physical meetings. The respondents had all been using social media, and Facebook specifically, professionally for about two to four years but considered the municipality as being in the start-up phase of their social media use.

The interviews took between 40 and 90 minutes each and were transcribed verbatim and continually analysed. The interviews were followed up by a participantobservation in a reflection workshop with communicators and communication managers from seven different municipalities in the same region. A total of 16 people participated in the workshop. Three of the interviewees were also participants in the workshop. The workshop was audio recorded and afterwards listened to while notes were taken.

The data collection was guided by a general, open-minded curiosity about finding out why municipalities were not using social media to its full potential, as related research told us. The data collection was therefore inductively conducted with openended interviews and workshop questions [44] about the start-up of social media in the municipality, its use today and thoughts about the future (Table 1). The aim was to grasp what the respondents themselves found were important aspects of social media use.

\begin{tabular}{|l|l|}
\hline Question themes & Aim/purpose \\
\hline $\begin{array}{l}\text { Start-up process and present } \\
\text { organisation of social media }\end{array}$ & $\begin{array}{l}\text { Get an overview of how use of social media was } \\
\text { initiated in the municipality and how it is organized } \\
\text { today, i.e., how diffused social media is in the } \\
\text { organization and who is responsible for which } \\
\text { channels. }\end{array}$ \\
\hline Present social media use & $\begin{array}{l}\text { Gain a deeper understanding of how social media is } \\
\text { used in the municipality in general and at the } \\
\text { management level in particular, with focus on how } \\
\text { strategies and policies, potential opportunities and } \\
\text { challenges are understood and acted on. }\end{array}$ \\
\hline Future social media use & $\begin{array}{l}\text { Get insight into perceived trends, upcoming } \\
\text { cooperation with other organizations, future } \\
\text { opportunities and challenges - related to social media } \\
\text { in the municipality. }\end{array}$ \\
\hline
\end{tabular}

Table 1. Main themes and the researchers' purposes of the themes from the interviews and workshop.

\subsection{Data Analyses}

To get an overview of the collected data material, text documents from interview transcripts and workshop notes were read through multiple times. Content analyses [45] was conducted and resulted in two main categories, described in the next section. The theoretical lens of boundary object, boundary crossing and learning mechanisms 
at the boundaries did not guide the categorization but instead emerged as a possible tool for interpretation and explanation of the empirical findings later on during the analyses.

\section{Findings}

Based on the content analysis two main categories were identified: one category mapping the motives for social media use, and one category describing the perceived tensions emerging in the social media practice.

\subsection{Motives for Social Media Use}

Provide civic information. All communicators suggested that the main motivation for using social media was to provide the citizens with fast and easily accessible civic information, which was said to be part of a transparent and open approach. Civic information could be news about upcoming events and meetings in the city council or practical information about e.g. road closures, reconstruction work or weather information.

Increase democracy. The communicators also emphasized the importance of social media as a forum for increased democracy where citizens could ventilate opinions and feelings about their municipality. The role of the communicators was not to govern but rather to bring up relevant issues that the citizens can react to in their own forums: 'Sometimes the discussion continues by itself on social media and citizens reply to each other [...] It's a nice feeling when the citizens support us. Then we feel we are doing the right thing'. The response they get from citizens was said to be important for their own future work: 'Social media is a way of taking the temperature of the municipality's work and to see how the citizens react on information and activities'.

Promote the Municipality. Promoting the municipality was an additional important strategy. To promote the municipality meant to shed light on positive news, make the citizens feel proud of their region and make outsiders want to work and live in the municipality: 'It's about showing the municipality from its best side to make citizens feel proud [...] It's about external communication and a little bit of marketing'.

Network and Manage Emergency Response. Some participants emphasized the importance of social media for building an extensive network: 'In case of an emergency it is important to be able to instantly reach out to as many citizens as possible'. It was a common view that it is difficult to get response from citizens on social media, which is crucial to keeping the citizens in their networks. Therefore networking was about stimulating interaction, and not so much about pushing out information: 'It is less important what is posted but from the perspective of preparing for an emergency it is important to have a well-used trail and make it as much used as possible. It's about building network. To pat the users [citizens] a bit so that we get a response when it's needed'.

The motives mentioned above were not always easy to turn into action. The following section describes the tensions emerging in the actual social media practice. 


\subsection{Emerging tensions in social media practice}

Increased and reduced control. A feeling of lack of control over how the posts will be understood and responded to by citizens was expressed to be always present: 'I do a great deal of writing on the website and that's never any problem, but when I am about to write a Facebook post I always get nervous [...] what you are scared of is that the posts reach so many people and that it spreads so fast'. The worry was related to the lack of control over what citizens' reactions would be: 'We never know what the responses will be. A post that we find positive might as well turn out to be a negative posting according to the citizens'.

However, the feeling of reduced control was mixed with a feeling of increased control. The openness and immediacy of Facebook gives the communicator a chance to control the communication: 'The negative dialogue will always be there. That it's taking place in social media is just good because then it's visible. And we can respond to it immediately'. In that sense, the dialogue as such was valuable, no matter whether it is driven by citizens' satisfaction or displeasure. Thus, the potential fast and vast spread was perceived as scary and uncontrollable, but also contributed to valuable opinions that could easily be followed up before it went viral, which instead increased the control over the communication.

Personal and authoritative content and tone. Another cluster of challenges were related to the struggle to balance a personal content and tone with a more formal and neutral approach. Because communicators are public servants and not politicians not all topics were considered suitable in social media: 'Topics related to unemployment, housing shortage and refugee issues are better published on the website with a link to our official e-mail address in order to avoid generating racist and bitter discussions [...] the negative spreads very fast in social media so sometimes it's better to choose channels that you can more easily control'. At the same time as they struggled to be neutral and avoid political topics they were also strongly driven by the potential of social media for openness, transparency and a democratic approach. All of the communicators emphasized the importance of letting the citizens decide what topics were important or not. Here we see a tension between the communicators' motives to be democratic and let everyone speak about anything, at the same time as they feel they need to be neutral and keep control of political discussions.

Neutrality was also about not being too personal: 'The citizens should feel that it is the public employee that is the voice of the municipality and that there is a thought behind the posting that is neutral'. The problem with neutral postings such as civic information was that they got very little response on Facebook: 'When I post an announcement about an upcoming meeting in the city council I get no response at all'. Instead postings with a more personal content and tone that reveals the person behind the post tended to get attention: 'They [the citizens] like when they see that we are also humans, eating lunch like anyone' [...] 'Most "liked" are posts with a good picture from the new plantings in the city, a check-in and a photo from the lunch restaurant or a man sweeping the streets from gravel after the snowy winter'.

In the next section the findings are discussed with the aim to understand how 
perceived tensions and motives are challenging the work and identity of the communicators at different boundaries.

\section{Discussion}

The communicators are boundary crossers in the sense that they operate in, between and beyond different communities. The three main communities are public servants, elected officials and citizens. The communities are connected with a boundary object, in this case the municipal Facebook page. The Facebook page is open in its character and admits anyone in any of the communities to participate in the dialogue. The open approach allows for multiple communicative connections. One can argue that the communicators are actively participating in a boundary practice where their activities at the boundaries are challenging, but of vital importance.

The communicators' main motives for social media use are to reach out to citizens, enable forums and issues for discussion, get feedback and build networks. To do so they need to be both accountable and neutral as well as responsive and personal. This is not always easy and tensions between increased and decreased control and personal and authoritative approach on Facebook are a fact.

The discussion section continues with the argumentation that the sometimes difficult work of the communicators as boundary crossers has a lot of learning potential. The tensions occurring in the social media practice trigger processes of negotiation of both the communicators' professional identity as well as their coordination of work.

\subsection{Negotiation of identity}

To be professional in social media means to balance an authoritative approach with a more personal attitude. Neutrality is important for the municipal communicators when they define their own identity and try to make it clearly separate from that of citizens, elected officials and from the private domain. The process of keeping a distance to the citizens is a process of othering, and involves showing good knowledge of the organization by notifying about news and events and being informative, correct and politically independent. In the process of othering the relationship between the communicators and citizens can be understood as a boundary that becomes important to control and uphold. A process of othering can also be seen between the communicators and the elected officials. Here too, the boundary is to be maintained and controlled. It is not included in the role of the municipal communicator to defend political decisions or debate sensitive issues. Therefore posts are kept neutral both in content and tone. Issues regarding sensitive concerns, such as refugees, unemployment etc. are avoided because of the lack of control of the speed and spread of potential citizens' comments. Thus, to keep a distance is at the same time to preserve a boundary.

However, the boundaries are not only controlled and upheld, they are also crossed. A main motive for social media use in the municipality is to increase democracy by involving the citizens in the municipality's activities and to receive feedback on existing work. To do so the communicators need to reach out and make citizens engaged in what they are saying and doing. They strive, to some extent, to achieve a 
legitimatized co-existence with the citizens. This includes attempts to get feedback from the citizens so they know if their work is interesting enough, and to make citizens share and co-create what they are posting. Such work means changing the social media strategy from push of content to pull of feedback as well as adopting a more persuasive networking approach [37]. The social media activity needs to enable the citizens to develop an interest in municipal activities, discuss and make sense of the activities and spread it to their own social media channels and in the physical world. For this to happen content and tone needs to be relevant, personal and clearly directed to citizens. The communicators need to cross the boundary between the citizens and the public servants, and keep one foot in the citizens' world, in order to be one of them. This is difficult since upholding the boundary and the communicator's professional identity are equally important.

The upholding and crossing of boundaries between the different communities show how the communicators negotiate their professional identity both in processes of othering and processes of legitimating co-existence. In the process of othering they try to bring out the character of a public servant and make that identity visible in the social media practice. The boundary between public servants and citizens is defined and defended. In the process of legitimating co-existence the communicators step over the boundary and become one of the citizens. This process means a practice where content and tone speak directly to the citizens. The tone is personal and the content related to citizens' everyday life.

In this sense the communicators' social media practice means working at the boundary between two or more diverse groups with one foot on each site and with the aim to build bridges. But it is also about not having a foot on any site. The lack of a home on any site is mirrored in the fact that the communicators cannot act as public servants are supposed to, because then they will not reach out. But at the same time it is not always considered professional behavior to act as a civic person because that will not give a cohesive impression of the communicator and the municipality.

\subsection{Coordination of Work}

Work at boundaries between diverse groups can also be understood as processes of coordination in order to maintain the work flow. Coordination requires communicative connections, efforts of translation, enhanced boundary permeability and routinization [40]. What is posted in social media can be understood as a 'boundary object' giving rise to communicative connection between different actors. The municipal general Facebook page, in this case, is one place where citizens meet the municipality. Since Facebook, as used in the municipality, is open in its character and admits anyone to join the conversation, it connects not only the main target group (citizens), but also other potential actors such as e.g. private friends, family, colleagues etc. And moreover, the target group (citizens) is diverse as such since it represents the whole population. The boundary object is in this perspective connecting a potential diversity of actors, which makes it difficult for the municipal communicators to anticipate how posts are going to be understood and replied to. This uncertainty, related to tensions between strategies and what is appropriate to do as a public servant, tends to slow down the workflow. Moreover, the multiple sites and communicative connections tend to flatten the social media presence. When the audience is everyone content and tone 
are made neutral, and even if posts are informative and correct, they do not reach out.

To view the social media practice as an effort of translation can be useful in order to understand the importance of adjusting the posts to their different target groups. Efforts of translation can, in this context, be related to the efforts of making the municipal activities translated into a content and tone that is understandable, but also stimulating and engaging. Such translation of posts on Facebook have the potential to stimulate reaction from the citizens and consequently be spread. Today only one single translation of the municipal activities in social media is done. To view effort of translation as a learning process can help communicators to work with more nuanced strategies for reaching out, e.g. working more strategically with channel choice and target groups could limit the number of potential communicative connections, which might reduce the hesitation and hence improve the workflow.

All communicators in the study describe variously how they are in the start-up phase of social media use in the municipality. Even the citizens are not very experienced in how to communicate with the government in social media since social media has so far mainly been used for private communication purposes [24]. That can explain why social media practice in the municipality is to some extent still missing enhanced boundary permeability and processes of routinization, i.e., why interactions at the boundaries are demanding and the discontinuities experienced as troublesome rather than developing. However, the study shows how the communicators are repeatedly crossing boundaries to reach out and develop the municipality towards a more participatory government. And in those processes roles and identities of the communicators are constantly negotiated and developed towards what seems to be a new emerging practice within e-government.

\section{Implications and Conclusion}

Social media with its new technological features and user-generated content, in combination with a public audience that has long adopted social media for private use, creates new challenges for the municipality. E-participation is no longer a matter relevant only on the agenda of elected officials, but public servants, like the communicators in this study, also need to act as representatives for the democratic ideals in the municipality. Municipal service not only means serving standard formatted information to the citizens in a top-down, one-way direction. Rather, with social media as a driving force, a more participatory approach is starting to emerge, in which the citizens, together with the public servants define the agendas, arenas and activities.

However, this new way of enabling service to the citizens challenges both the identity of the communicators as well as the organization of their work. Social media constantly strains what is legitimate to do as a public servant and what ought to be done in order to improve e-participation. The different processes of negotiations outlined in this paper can be understood as learning processes towards a new role of the municipal communicator, and perhaps public servants in general. The new role means being a mediator between the elected officials and the citizens and it means a different kind of nearness to citizens. The reason for why the learning processes are sometimes hard could be explained by lack of necessary social media and e- 
participation skills. The communicators are trained to serve the citizens but not necessarily to enact democracy logics, i.e., problematize democratic ideals and put them into action.

The constant negotiation of identity and coordination of work, as we show in this study, can then be understood as a learning process towards improved competence for public servants where democratic logics and social media skills seem to be crucial ingredients and where boundary-crossing activities are an embedded part of the expertise.

\section{Further Research}

Future research could further explore the cooperation between public servants and elected officials. How explicit is this cooperation to the actors today? How could the cooperation be developed for even better e-participation? And how generalizable are the findings in this study for public servants in general? Furthermore, social media and e-participation activities are challenging not only those boundaries brought up in this article. To get a more complete understanding of the new role of the communicator, additional boundaries and boundary crossing activities need to be explored. Two examples of a boundaries that are not mentioned in this study are those between workplace and home and between different workplaces. How is the professional role of public servant communicators affected by the fact that social media blurs both spatial and temporal aspects of work, e.g. municipal Facebook feed is checked on free time and colleagues are 'friends' on private Facebook accounts? And how is social media use and e-participation negotiated in online forums such as e.g. national Facebook groups for social media in public sector?

\section{References}

1. Kahn, G.F., Yoon, H.Y., Kim, J., Park, H.W.: From e-government to social government: Twitter use by Korea's central government. Online Information Review. 38.1, 95-113 (2012)

2. Bertot, C.J., Jaeger, P.T., Grimes, J.M.: Using ICTs to create a culture of transparency: Egovernment and social media as openness and anti-corruption tools for societies. Government Information Quarterly. 27.3, 264-271 (2010)

3. Golbeck, J., Grimes, J. M., \& Rogers, A.: Twitter use by the US Congress. Journal of the American Society for Information Science and Technology, 61(8), 1612-1621 (2010)

4. Bernhard, I.: E-government and e-governance: Local implementation of e-government policies in Sweden. Doctoral thesis, The Royal Institute of Technology, Stockholm, Sweden (2014) http://www.diva-portal.org/smash/get/diva2:750658/FULLTEXT02.pdf

5. Briggs, X. S.: Democracy as problem solving: Civic capacity in communities across the globe. Cambridge, MA: MIT Press (2008)

6. Richard, H., Rohm, A., Crittenden, V.: We're all connected: The power of the social media ecosystem. Business Horizons. 54.3, 256-273 (2011)

7. Findahl, O. \& Davidsson, P.: Svenskarna och Internet 2015. En årlig studie av svenska folkets internetvanor. [The Swedes and the Internet 2015]. 1st ed. iis.se. www.soi2015.se extracted 2016-02-17 (2015)

8. Kavanaugh, A. L., Fox, E. A., Sheetz, S. D., Yang, S., Li, L. T., Shoemaker, D. J. \& Xie, L.: Social media use by government: From the routine to the critical. Government 
Information Quarterly, 29(4), 480-491 (2012)

9. Jansson, G.: En legitim (elektronisk) förvaltning? Om IT-utveckling i kommunal förvaltning, Doctoral thesis, Linköping. Linköping University (2013)

10.OECD.: Public sector innovations and e-Government in OECD, Government at a Glance 2013. Retrieved March 1, 2014 from http://www.oecd.org/gov/public-innovation/ (2013)

11. Mossberger, K., Yonghong, W. \& Crawford, J.: Connecting citizens and local governments? Social media and interactivity in major US cities. Government Information Quarterly 30 (4), 351-358 (2013)

12. Chadwick, A.: Web 2.0: New challenges for e-democracy in an era of informational exuberance. I/S: A Journal of Law and Policy for the Information Society, 5(1), 9-42 (2009)

13. Coursey, D., \& Norris, D. F.: Models of e-government: Are they correct? An empirical assessment. Public Administration Review, 68 (3), 523-536 (2008)

14. Øystein, S., Rose, J., Skiftenes Flak, L.: The shape of eParticipation: Characterizing an emerging research area. Government Information Quarterly. 25.3, 400-428 (2008)

15. Oakerson, R. J.: Governing Local Public Economies: Creating the Civic Metropolis. Richmond: ICS Press (1999)

16. Taylor-Smith, E. \& Lindner, R.: Social networking tools supporting constructive involvement throughout the policy-cycle. Proceedings of 2010 4th International Conference on Electronic Democracy, Centre for E-Government (2010)

17. SALAR: E-tjänster och appar - hur är läget i kommunerna? E-Förvaltning och E-Tjänster $i$ Kommunerna 2014. Stockholm: Sveriges kommuner och landsting [The Swedish Association of Municipalities and Regions] (2014)

18. Bonsón, E., Torres, L., Royo, S., Flores, F.: Local e-government 2.0: Social media and corporate transparency in municipalities. Government Information Quarterly, 29, 123-132 (2012)

19. Larsson, A. O.: Bringing it all back home? Social media practices by Swedish municipalities. European Journal of Communication (2014).

20. Dixon, B. E.: Towards e-government 2.0: an assessment of where e-government 2.0 is and where it is headed. Public Administration \& Management, 15(2) (2010)

21. Giritli Nygren, K. \& Wiklund, H. G.: En IT-styrd förvaltning - en fjärde förvaltningsdoktrin? In K. Lindblad-Gidlund, A. Ekelin, S. Eriksén \& A. Ranerup (Eds.) Förvaltning och medborgarskap i förändring, (In English: Ongoing changes in public administration and citizenship - established practice and critical perspectives), Lund: Studentlitteratur, 215-227 (2010)

22.Kolsaker, A., \& Lee-Kelley, L.: Citizens' attitudes towards e-government and e-governance: a UK study. International Journal of Public Sector Management 21 (7), 723-738 (2008)

23. Ellison, N. \& Hardey, M.: Developing political conversations? Social media and English local authorities. Information, Communication \& Society 16.6 (2013), 878-898 (2013)

24. Kaplan, A.M., Haenlein, M.: Users of the world, unite! The challenges and opportunities of Social Media. Business Horizons 53.1, 59-68 (2010)

25.Grönlund, A. What's in a Field - Exploring the Egovernment Domain, Social Science Computer Review, 21 (1), 55-72 (2005)

26.Bernhard, I. E-government and e-governance: Local implementation of e-government policies in Sweden. Doctoral thesis, The Royal Institute of Technology, Stockholm, Sweden. http://www.diva-portal.org/smash/get/diva2:750658/FULLTEXT02.pdf. (2014)

27.Charalabidis, Y., \& Loukis E.: Transforming government agencies' approach to eparticipation through efficient exploitation of social media. ECIS (2011)

28.Johannessen, M. R., Skiftenes Flak, L., Sæbø, Ø.: Choosing the Right Medium for Municipal eParticipation Based on Stakeholder Expectations. In: Electronic Participation pp. 25-36, Springer Berlin Heidelberg (2012)

29. Feldman, M., Hadjimichael, T., Lanahan, L., \& Kemeny, T.: The logic of economic 
development: A definition and model for investment. Environment and Planning C: Government and Policy: 0263774X15614653 (2015)

30. Leonardi, P. M.: Materiality, Sociomateriality, and Socio-Technical Systems: What Do These Terms Mean? How Are They Different? Do We Need Them?. In: Leonardi, P. M., Nardi, B. A., \& Kallinikos, J. (eds.) pp. 25-48. Materiality and organizing: Social interaction in a technological world. Oxford University Press on Demand (2012)

31. Scott, S. V., \& Orlikowski, W. J.: Great Expectations: The Materiality of Commensurability in Social Media. In: Leonardi, P. M., Nardi, B. A., \& Kallinikos, J. (eds.) pp. 113-133. Materiality and organizing: Social interaction in a technological world. Oxford University Press on Demand (2012)

32. Bertot, C. J., Jaeger, P. T \& Grimes, J. M.: Promoting transparency and accountability through ICTs, social media, and collaborative e-government. Transforming Government: People, Process and Policy 6.1, 78-91 (2012)

33. Rainie, L., Wellman, B.: Networked: The new operating system. MIT Press, Cambridge, Massachusetts (2012)

34. Yoo, Y., Boland Jr, R. J., Lyytinen, K., \& Majchrzak, A.: Organizing for innovation in the digitized world. Organization Science, 23(5), 1398-1408 (2012)

35. Sæbø, Ø., Rose, J., \& Nyvang, T.: The role of social networking services in eParticipation. Electronic participation. Springer Berlin Heidelberg, 46-55 (2009)

36. Tolbert, C. J., \& Mossberger, K.: The effects of e-government on trust and confidence in government. Public Administration Review, 66 (3), 354-369 (2006)

37. Mergel, I. Social media adoption and resulting tactics in the US federal government. Government Information Quarterly, 30(2), 123-130 (2013)

38. Facebook.: Facebook Help Center, Pages Basics. Retrieved March 31, 2016 from https://www.facebook.com/help/281592001947683/ (2010)

39. Facebook.: Facebook for Business, Organic Reach on Facebook: Your Questions Answered. Retrieved March 31, 2016 from https://www.facebook.com/business/news/Organic-Reach-on-Facebook (2014)

40. Akkerman, S. F., \& Bakker, A.: Boundary crossing and boundary objects. Review of Educational Research, 81(2), 132-169 (2011)

41. Star, S. L. (2010). This is not a boundary object: Reflections on the origin of a concept. Science, Technology \& Human Values, 35(5), 601-617.

42. Cecez-Kecmanovic, D., Galliers, R. D., Henfridsson, O., Newell, S., and Vidgen, R.: The sociomateriality of information systems: Current status, future directions. MIS Quarterly, 38(3), 809-830 (2014)

43. Treem, J. W., and Leonardi, P. M.: Social media use in organizations: Exploring the affordances of visibility, editability, persistence, and association. Communication Yearbook, $36,143-189$ (2012)

44. Kvale, S., \& Brinkmann, S. Interviews: Learning the craft of qualitative research interviewing. Sage. (2009)

45. Bryman, A. Social research methods. Oxford university press. (2015) 